\title{
AIR QUALITY INDICES - CASE STUDY: ENVIRONMENTAL SUSTAINABILITY PILLAR AND ROMANIA'S POSITIONING IN THE EUROPEAN AND GLOBAL CONTEXT
}

\author{
Ioan-Bogdan BACOȘ, Manuela Rozalia GABOR \\ 1. “George Emil Palade” University of Medicine, Pharmacy, Sciences and Technology of Târgu Mureș, \\ bacos.bogdan@yahool.com,bacos.ioan-bogdan.20@stud.umfst.ro \\ 2 “George Emil Palade” University of Medicine, Pharmacy, Sciences and Technology of Târgu Mureș, \\ manuela.gabor@umfst.ro
}

\begin{abstract}
Daily exposure to ambient air pollutants harms human health and the environment. Even though in recent years air quality is a taboo subject discussed and researched by many interested areas, pollution indices often exceed the pollution norms imposed by the authorities in major European cities. In response to these environmental problems, the European Union has created a body of legislation on pollution indicators. On the other hand, World Economic Forum promote the travel tourism competitiveness index (including the pillar of environmental sustainability). The purpose of this paper is to present and analyse the indicators from the environmental sustainability pillar within TTCI (Travel and tourism competitiveness index) and the air pollution indicators, respectively the air quality standards and the pollution norms. As a short result, România exceeds at some indicators and has a lot to improve at the others (Enforcement of environmental regulations).
\end{abstract}

Key words: Air quality indices; regulations; air pollutants; human health; environment; tourism industry

\section{Introduction}

Air pollutants stand out in nature through their different action on the human body and the environment [1]. Thus, in nature, pollutants are classified according to different characteristics, such as: chemical composition, persistence in the environment, ability to be transported, reactions, impact on human health and the environment [2]; [3]; [4].

Even though the term environmental pollution has been recognized since industrial revolutions by an important category of people, there are several authors [5]; [6]; [7], [8]; [9], which integrates the term environmental quality into the quality of natural attractions, thus resulting in qualitative destinations in terms of the environment. The emergence of the term air quality comes with the technologizing of medicine and awareness of health problems related to mass pollution [10]. According to the director of the Clean Air Project, part of the Climate and Clean Energy program at NRDC (The Natural Resources Defence Council) concern that "the most air pollution comes from energy use and production" (John Walke) [11]. Therefore, the climate change, human impact, and daily innovation, make the fight against air pollutant's even harder to achieve the worldwide pollution standards [12].

(C) 2021 Published by University Press. This is an open access article under the CC BY-NC-ND license (http://creativecommons.org/licenses/CC-BY-4.0/) 
Sustainable development is a dynamic concept, with many dimensions and interpretations, seen as a process of permanent change, very connected to the national and local context, national and local needs and priorities [13].

Understanding and using the word "environment" often tends to be associated with human impact on natural systems [14]. This context differs from the word 'ecological', which can be characterized as a concept of interdependence of elements in a system [15].

The main objective is the analysis of the indicators from the environmental sustainability pillar within TTCI (Travel and tourism competitiveness index) and the air pollution indicators, respectively the air quality standards and the pollution norms.

The second objective is the conceptual evolution of the above-mentioned indicators and the analysis of Romania's competitive position in the international tourism industry [16].

The advantages of data analysis show us Romania's position in a global context in terms of environmental sustainability and the data differences found between the years of biennial reporting.

Given the complexity of the research and the various dimensions of tourism, on the one hand, and the high interest in air quality standardization, we will address an interpretation and analysis of data both qualitatively and quantitatively. Also, as our main contribution to research was to simplify TTCI data and extract correlated indicators of environmental sustainability, thus facilitating the analysis of data for the years studied: 2009, 2011, 2013, 2015, 2017 and finally 2019.

The quantitative approach will verify the research hypotheses, to confirm them in order to exist the relationship between air quality and tourism.

\section{Methodology}

\section{Environmental sustainability pillar in the tourism industry}

Since 2007, the World Economic Forum (WEF) has started formulating indices that analyse the competitiveness of the tourism industry (TTCI) [17]. This system of indicators reports and measures the competitiveness of the major tourist destinations around the world, with the objective of assessing the factors and policies that make it an attractive destination for international tourism.

By hiring tourism leaders, the World Economic Forum aims to conduct an in-depth analysis of the competitiveness of this sector.

Distributed biennially, the Travel and Tourism Competitiveness Report and Index compares the competitiveness of the tourism division of 140 worldwide economies and measures the set of components and arrangements that empower the economic improvement of the "Travel \& Tourism
(T\&T)" segment, which in turn contributes to a country's financial advancement and tourism competitiveness.

The indicator system was developed in the context of the World Economic Forum Industrial Programmed for Aviation, Travel and Tourism as part of the Platform for Shaping the Future of Travel Mobility. It is undertaken in close collaboration with data gatherers Bloom Consulting, STR Global, the International Air Transport Association (IATA), the International Union for Conservation of Nature (IUCN), the World Tourism Organization (WTW) and the World Travel \& Tourism Council (WTTC). Part of the sub-index of policies and conditions favourable to the tourism sector the environmental sustainability pillar expresses the degree of involvement of each country in the ethical protection of natural resources, in the current context of the major effects of pollution worldwide. The attraction of a location is the extent to which the environment, natural resources and ecosystems are seen by tourists and the conditions under which the tourism industry complies with these important factors.

\section{Air quality standards}

According to National Centre for Environmental Health [18], European Environment Agency [19] and World Health Organisation [20]. in March 2021 the most common air pollutants are:

- Gaseous pollutants (e.g., SO2, CO, NO2, ozone or volatile organic compounds)

- Persistent organic pollutants (e.g., insecticides, pesticides, dioxins).

- Toxic heavy metals (e.g., lead, mercury).

- Particulate matter (including PM2,5 and PM10, respectively, known as coarse and fine particulate matter, the most recently discovered air pollutants)

The specific air quality index, in short "specific index", is a system for coding the recorded concentrations for each of the following pollutants monitored. World Health Organizations (WHO) released the first air quality guideline in 2000 [21].

The selected EU standards and the most recent World Health Organization (WHO) guidelines are summarized in the table no.1, including the maximum concentration on specific period. 
Table 1- Air quality standards / specific period

\begin{tabular}{|c|c|c|}
\hline Pollutant & Concentration & Period \\
\hline \multirow{2}{*}{ PM 2.5} & $10 \mu \mathrm{g} / \mathrm{m} 3$ & 1 year \\
\hline & $25 \mu \mathrm{g} / \mathrm{m} 3$ & 24 hours \\
\hline \multirow{2}{*}{ PM 10} & $20 \mu \mathrm{g} / \mathrm{m} 3$ & 1 year \\
\hline & $50 \mu \mathrm{g} / \mathrm{m} 3$ & 24 hours \\
\hline \multirow{2}{*}{$\mathrm{SO} 2$} & $350 \mu \mathrm{g} / \mathrm{m} 3$ & 1 hour \\
\hline & $125 \mu \mathrm{g} / \mathrm{m} 3$ & 24 hours \\
\hline \multirow{2}{*}{$\mathrm{NO} 2$} & $40 \mu \mathrm{g} / \mathrm{m} 3$ & 1 year \\
\hline & $200 \mu \mathrm{g} / \mathrm{m} 3$ & 1 hour \\
\hline $\mathrm{CO}$ & $10 \mathrm{mg} / \mathrm{m} 3$ & $\begin{array}{c}\text { Max. } 8 \\
\text { hours/day }\end{array}$ \\
\hline Lead $(\mathrm{Pb})$ & $0.5 \mu \mathrm{g} / \mathrm{m} 3$ & 1 year \\
\hline Ozone & $120 \mu \mathrm{g} / \mathrm{m} 3$ & $\begin{array}{c}\text { Max. } 8 \\
\text { hour/day }\end{array}$ \\
\hline Arsenic (As) & $6 \mathrm{ng} / \mathrm{m} 3$ & 1 year \\
\hline Cadmium (Cd) & $5 \mathrm{ng} / \mathrm{m} 3$ & 1 year \\
\hline Nickel (Ni) & $20 \mathrm{ng} / \mathrm{m} 3$ & 1 year \\
\hline $\begin{array}{c}\text { Polycyclic } \\
\text { Aromatic } \\
\text { Hydrocarbons }\end{array}$ & $1 \mathrm{ng} / \mathrm{m} 3$ & 1 year \\
\hline
\end{tabular}

Source: Made by author according to the European Environmental Agency

The TTCI indicators, especially the indicators of the environmental sustainability pillar and the air quality standards have the role of highlighting the possibility of a competitive ranking area / country on the tourist market. The use in the analysis and research of the above-mentioned indicators, presents the possibility to be correlated together with other macroeconomic indicators and specific to the tourism industry, to create a hypothesis rarely found in tourism: tourists prefer destinations that enjoy higher air quality compared to others.

\section{Results and discussion}

Europe remains the most competitive region in terms of tourism. Europe is home to six of the top 10 economies with scores and has some of the best cultural resources in the world, leading infrastructure, especially for land, port and tourist infrastructure.

The region also has the best favourable policies and conditions applicable to the tourism sector. Despite its history and 'oldness' in the market, the region was also the most favourable region in the 2017 report, being at the top of price competitiveness, air transport infrastructure and ICT promptitude. While Western, Southern and Northern Europe remain the competitive core of the region, the Balkan regions and the subregions of Eastern Europe and Eurasia recorded the highest average increase in the TTCI score.

Since 2007, Romania has been included in the reports on the system of indicators of tourist competitiveness. According to the data analysed, Romania ranks in the middle of the ranking in each report carried out. However, according to Table 2 we can see a major increase from the 2017 report, where Romania ranks 68th, to a 56th place ranking, while all countries/economies want to grow or remain at the top of the ranking.
Table 2- Evolution of Romania and the countries analysed in the ranking of the system of indicators of tourist competitiveness

\begin{tabular}{|l|c|c|c|c|c|c|c|}
\hline Year & 200 & 200 & 201 & 201 & 201 & 201 & 201 \\
& 7 & 9 & 1 & 3 & 5 & 7 & 9 \\
\hline $\begin{array}{l}\text { Countri } \\
\text { es }\end{array}$ & 124 & 133 & 139 & 140 & 141 & 136 & 140 \\
\hline Position & 63 & 66 & 63 & 68 & 66 & 68 & 56 \\
\hline
\end{tabular}

Part of the sub-index of policies and conditions favourable to the tourism sector the environmental sustainability pillar expresses the degree of involvement of each country in the ethical protection of natural resources in the current context of the major effects of pollution worldwide (ANM) .The attraction of a location is the extent to which the environment, natural resources and ecosystems are seen by tourists and the conditions under which the tourism industry complies with these important factors.

The 10 indicators (and a short description) that make up the Tourism Sustainability Pillar can be found in the table below.

Table 3 Environmental Sustainability Pillar Indicators and Their Description

\begin{tabular}{|c|c|}
\hline Name & Description \\
\hline $\begin{array}{l}\text { Stringency of } \\
\text { environmental } \\
\text { regulations }\end{array}$ & $\begin{array}{l}\text { The emphasis on the reuse of } \\
\text { resources in a 'circular' economy and } \\
\text { the number of wastes to reach } 0 \text {. }\end{array}$ \\
\hline $\begin{array}{l}\text { Enforcement } \\
\text { of } \\
\text { environmental } \\
\text { regulations }\end{array}$ & $\begin{array}{l}\text { Involvement of government and local } \\
\text { authorities in the implementation of } \\
\text { proposed environmental regulations } \\
\text { and the application of sanctions where } \\
\text { they are not respected. }\end{array}$ \\
\hline $\begin{array}{l}\text { Sustainability } \\
\text { of travel and } \\
\text { tourism } \\
\text { industry } \\
\text { development }\end{array}$ & $\begin{array}{l}\text { Development and modelling of the } \\
\text { industry with the aim of protecting } \\
\text { natural resources and the material } \\
\text { base of the industry. }\end{array}$ \\
\hline $\begin{array}{l}\text { Particulate } \\
\text { matter } \\
(\mathrm{PM} 2,5) \\
\text { concentration }\end{array}$ & $\begin{array}{l}\text { PM2.5 are tiny particles in the air that } \\
\text { reduce visibility and make the air } \\
\text { blurry when levels are high. Exposure } \\
\text { to fine particles can cause short-term } \\
\text { health effects such as eye, nose, throat } \\
\text { and lung irritation, cough, sneezing, } \\
\text { runny nose and shortness of breath. }\end{array}$ \\
\hline $\begin{array}{l}\text { Environmental } \\
\text { treaty } \\
\text { ratification }\end{array}$ & $\begin{array}{l}\text { International agreement of } 29 \\
\text { environmental treaties that should be } \\
\text { applied in each country }\end{array}$ \\
\hline $\begin{array}{l}\text { Baseline water } \\
\text { stress }\end{array}$ & $\begin{array}{l}\text { Water stress affects the ratio of total } \\
\text { water use to the annual total available } \\
\text { water }\end{array}$ \\
\hline $\begin{array}{l}\text { Threatened } \\
\text { species }\end{array}$ & $\begin{array}{l}\text { Lists endangered animals in a } \\
\text { region/country considering the } \\
\text { authorities' measures to protect them }\end{array}$ \\
\hline $\begin{array}{l}\text { Forest cover } \\
\text { change }\end{array}$ & $\begin{array}{l}\text { Represents the measure/percentage in } \\
\text { which old forests are rejuvenated. } \\
\text { This indicator also includes the } \\
\text { restoration of forest areas after } \\
\text { massive falls. }\end{array}$ \\
\hline $\begin{array}{c}\text { Wastewater } \\
\text { treatment }\end{array}$ & $\begin{array}{l}\text { It is a concern for the environment } \\
\text { from many perspectives. First it is } \\
\text { necessary to have water treatment }\end{array}$ \\
\hline
\end{tabular}




\begin{tabular}{|c|l|}
\hline & $\begin{array}{l}\text { systems, then to encourage } \\
\text { companies to use water and not least } \\
\text { to stimulate responsible water } \\
\text { consumption among tourists }\end{array}$ \\
\hline $\begin{array}{c}\text { Fish stock } \\
\text { status }\end{array}$ & Fish stocks \\
\hline
\end{tabular}

For a detailed analysis of these 10 indicators, we can see Romania's current position on tourist competitiveness in the 2019 WEF report [22]. According to the information also specified in table 4 on Environmental Sustainability Indicators, the score obtained, the ranking position, the average value and the highest ranked countries, we see a better positioning for the indicator on " Environmental treaty ratification " (score 25/27, heading 27/140). The lowest ranked was the "Sustainability of travel and tourism industry development " indicator well below average (heading 113/140). There is also an indicator with no data being shaved, namely 'Live fish stock'.

\begin{tabular}{|l|c|c|c|}
\multicolumn{4}{|c}{$\begin{array}{c}\text { Table } 4 \text { Environmental Sustainability Pillar } \\
\text { Indicators }\end{array}$} \\
\hline $\begin{array}{l}\text { Index compont Romania } \\
\text { 2019 }\end{array}$ \\
\hline $\begin{array}{l}\text { Environmental } \\
\text { sustainability }\end{array}$ & Value & $\begin{array}{c}\text { Rank } \\
\mathbf{1 / 1 4 0}\end{array}$ & $\begin{array}{l}\text { Best } \\
\text { performer }\end{array}$ \\
\hline $\begin{array}{l}\text { Stringency of } \\
\text { environmental } \\
\text { regulations }\end{array}$ & 4.5 & 45 & Switzerland \\
\hline $\begin{array}{l}\text { Enforcement of } \\
\text { environmental } \\
\text { regulations }\end{array}$ & 3.3 & 103 & Finland \\
\hline $\begin{array}{l}\text { Sustainability of } \\
\text { travel and tourism } \\
\text { industry } \\
\text { development }\end{array}$ & 3.5 & 113 & Lesotho \\
\hline $\begin{array}{l}\text { Particulate matter } \\
\text { (PM2,5) } \\
\text { concentration }\end{array}$ & 16.1 & 102 & Mauritius \\
\hline $\begin{array}{l}\text { Environmental } \\
\text { treaty ratification }\end{array}$ & 25 & 27 & Multiple \\
\hline $\begin{array}{l}\text { Baseline water } \\
\text { stress }\end{array}$ & 1.3 & 60 & Multiple \\
\hline $\begin{array}{l}\text { Threatened species } \\
\text { Forest cover change }\end{array}$ & 5.9 & 73 & Luxembourg \\
\hline $\begin{array}{l}\text { Wastewater } \\
\text { treatment }\end{array}$ & 22.8 & 58 & Multiples \\
\hline \begin{tabular}{l} 
Fish stock status \\
\hline
\end{tabular} & $\mathrm{n} / \mathrm{a}$ & $\mathrm{n} / \mathrm{a}$ & Yemen \\
\hline
\end{tabular}

The evolution of the Environmental Sustainability Pillar on Romania's reports in the system of indicators of tourist competitiveness began from the 2009 report. For the first three reports, the pillar contains only 7 relevant indicators, with the current 10 indicators to be updated from 2015.

According to table 5, in 2009 Romania ranked 6th in the ranking in terms of the indicator on "Concentration of fine particles". The insufficiency of the data thus ranks Romania in the primary positions in the first reports [23]. Thus, the relevant data on Fine Particle Concentration will only be considered in the 20152019 reports.
Table 5. Environmental Sustainability Pillar Indicators - Report Romania 2009

\begin{tabular}{|l|c|}
\hline \multicolumn{1}{|c|}{ Index component } & Rank/133 \\
\hline Stringency of environmental regulations & 60 \\
\hline Enforcement of environmental regulations & 67 \\
\hline $\begin{array}{l}\text { Sustainability of travel and tourism industry } \\
\text { development }\end{array}$ & 121 \\
\hline Carbon dioxide emissions & 71 \\
\hline Particulate matter concentration & 6 \\
\hline Threatened species & 62 \\
\hline Environmental treaty rectification & 34 \\
\hline
\end{tabular}

Table 6 looks at the same 7 pillars and we can see an increase in the 'Carbon Emissions' indicator from heading 71 in 2009 to heading 74 in 2011 [24].

Table 6 Environmental Sustainability Pillar Indicators Report Romania 2011

\begin{tabular}{|l|c|}
\hline \multicolumn{1}{|c}{ Index component } & Rank/139 \\
\hline Stringency of environmental regulations & 71 \\
\hline Enforcement of environmental regulations & 88 \\
\hline $\begin{array}{l}\text { Sustainability of travel and tourism } \\
\text { industry development }\end{array}$ & 118 \\
\hline Carbon dioxide emissions & 74 \\
\hline Particulate matter concentration & 7 \\
\hline Threatened species & 61 \\
\hline Environmental treaty rectification & 30 \\
\hline
\end{tabular}

The 2013 report [25] (Table 7) finds Romania from the perspective of the "Environmental Sustainability" pillar at 58th position, where Romania ranks 128/140 in the indicator of "Sustainability of the development of the tourism industry".

Table 7 Environmental Sustainability Pillar Indicators - Report Romania 2013

\begin{tabular}{|c|c|c|}
\hline Index component & Score & Rank/139 \\
\hline Environmental sustainability & 4.7 & 48 \\
\hline $\begin{array}{l}\text { Stringency of environmental } \\
\text { regulations }\end{array}$ & 3.2 & 109 \\
\hline $\begin{array}{l}\text { Enforcement of environmental } \\
\text { regulations }\end{array}$ & 3.0 & 101 \\
\hline $\begin{array}{l}\text { Sustainability of travel and } \\
\text { tourism industry development }\end{array}$ & 3.2 & 129 \\
\hline $\begin{array}{l}\text { Carbon dioxide emissions (mil } \\
\text { tons/capita) }\end{array}$ & 4.4 & 74 \\
\hline $\begin{array}{l}\text { Particulate matter } \\
\text { concentration }\left(\mathrm{ug} / \mathrm{m}^{3)}\right.\end{array}$ & 14.2 & 13 \\
\hline Threatened species (\%) & 4.8 & 66 \\
\hline $\begin{array}{l}\text { Environmental treaty } \\
\text { rectification }(0-25)\end{array}$ & 22 & 20 \\
\hline
\end{tabular}

Starting with the 2015 report [26], the 10-indicator variant is being switched to, as is also found in Figure 3.5. Analysing the data, Romania appears in this report 
at position 46 from the perspective of this pillar, 12 positions ranked better than in the 2013 report.

Table 8 Environmental Sustainability Pillar Indicators - Report Romania 2015

\begin{tabular}{|c|c|c|}
\hline Index component & Value & $\begin{array}{l}\text { Rank } \\
1 / 136\end{array}$ \\
\hline $\begin{array}{l}\text { Environmental } \\
\text { sustainability }\end{array}$ & 4.4 & 46 \\
\hline $\begin{array}{l}\text { Stringency of environmental } \\
\text { regulations }\end{array}$ & 3.8 & 90 \\
\hline $\begin{array}{l}\text { Enforcement of } \\
\text { environmental regulations }\end{array}$ & 3.7 & 77 \\
\hline $\begin{array}{l}\text { Sustainability of travel and } \\
\text { tourism industry } \\
\text { development }\end{array}$ & 3.4 & 122 \\
\hline $\begin{array}{l}\text { Particulate matter (PM2,5) } \\
\text { concentration }\end{array}$ & 14.9 & 124 \\
\hline $\begin{array}{l}\text { Environmental treaty } \\
\text { ratification }\end{array}$ & 22 & 28 \\
\hline Baseline water stress & 0.8 & 44 \\
\hline Threatened species & 4.8 & 60 \\
\hline Forest cover change & 1.0 & 35 \\
\hline Wastewater treatment & 13.1 & 71 \\
\hline Fish stock status & 0.0 & 6 \\
\hline
\end{tabular}

According to 2017's report (table 9), the WEF proceeds with 10 indicators also included in the 2019. Analysing the data, between the two reports, we see a better positioning of Romania from the perspective of this pillar (43 -2017, 48-2019) [27].

Compared to the latest report (table 4), we can see a difference according to the position of Romania in the Environmental sustainability pillar, in special with the Particular matter (2.5) index. According to those reports, Romania increased the pollution with PM 2.5, from $11.9 \mathrm{ug} / \mathrm{m}^{3}$ in 2017 to 16.1 in 2019.

Another important aspect to mention is the Sustainability of travel and tourism industry development index, which show a progressive ranking, from $121^{\text {st }}$ position in 2009 to $113^{\text {st }}$ in 2019.

Table 9 Environmental Sustainability Pillar Indicators - Report Romania 2017

\begin{tabular}{|l|c|c|}
\hline \multicolumn{1}{|c}{ Index component } & Value & $\begin{array}{c}\text { Rank } \\
\mathbf{1 / 1 3 6}\end{array}$ \\
\hline \multicolumn{1}{|c}{$\begin{array}{l}\text { Environmental } \\
\text { sustainability }\end{array}$} & $\mathbf{4 . 4}$ & $\mathbf{4 3}$ \\
\hline $\begin{array}{l}\text { Stringency of environmental } \\
\text { regulations }\end{array}$ & 3.8 & 79 \\
\hline $\begin{array}{l}\text { Enforcement of } \\
\text { environmental regulations }\end{array}$ & 3.3 & 98 \\
\hline $\begin{array}{l}\text { Sustainability of travel and } \\
\text { tourism industry } \\
\text { development }\end{array}$ & 2.8 & 130 \\
\hline $\begin{array}{l}\text { Particulate matter (PM2,5) } \\
\text { concentration }\end{array}$ & 11.9 & 111 \\
\hline $\begin{array}{l}\text { Environmental treaty } \\
\text { ratification }\end{array}$ & 25 & 26 \\
\hline $\begin{array}{l}\text { Baseline water stress } \\
\text { Threatened species }\end{array}$ & 1.3 & 58 \\
\hline Forest cover change & 0.2 & 70 \\
\hline $\begin{array}{l}\text { Wastewater treatment } \\
\text { Fish stock status }\end{array}$ & 15.4 & 40 \\
\hline
\end{tabular}

\section{Conclusion}

The social and environmental problems imposed on contemporary society in recent times are proving to be a great challenge for all economies. Environmental protection becomes an essential prerequisite for achieving sustainable competitive advantage and an integral part of the proactive management of the tourism industry.

Although the term air quality is often analysed by public health specialists and environmental analysts, existing studies show little attention to the influence of these quality indicators on the tourism industry [28]

Of the existing studies to analyse competitiveness in tourism, only a small part presents and analyses an interdependent relationship between air quality and strategic / competitive positioning of destinations [29], [30], [31] with lower air pollution rates, or so-called environmental competitiveness [32], [33], [34].

The analysis of the data regarding the studied indicators shows us Romania's position in the global context. A better position in the ranking, offers Romania a better strategic competitive position on the tourism industry market. Basically, these data can be used both by public authorities, to obtain better results in the following reports, and by private companies that can use this data to promote Romania as a sustainable tourist destination. Even the lack of data in some fields such as: forest cover change, or fish stock status; they can create a starting field for collecting data from the field and transmitting it for future reports.

The sustainable development and strategic positioning of Romania can represent a huge potential for the tourism sector and the growth of economies at the national level. Thus, emerging economies will contribute large proportions of travellers to this global trend and most national destinations can become more and more desirable by tourists, thus increasing the quality of the tourist products offered.

The main objective of the next papers is to study, analyse and present existing research and different approaches of the authors based on the topic "Air quality and its influence on the tourism industry", analysing both the terms of air quality related to the tourism industry and health also publishes the effects of pollution on the health of the pawns of this industry, tourists. According to the Global Sustainable Tourism Council and Booking's Sustainable Travel Report in $2019,70 \%$ of travellers around the world said that "they would be more likely to book accommodation, knowing that it is environmentally friendly and in a sustainable environment, regardless of whether the expenses are higher"'[11].

\section{References}

[1]. Arya, S. P. (1999). Air pollution meteorology and dispersion. Madison Avenue, New York: Oxford University.

[2]. Chen J., Mingguang T., Yulan L., Jian Z., Yuanmao Z., Zuci S., Guilin Z., Yan L (2008) -Characteristics of trace 
elements and lead isotope ratios in PM2.5 from four sites in Shanghai. J. Hazard. Mater. 156, pp 36-43

[3]. Cocheo C., Zaratin L., (2011) -Assessment of Human Exposure to Air Pollution, Encyclopedia of Environmental Health, Science Direct, pp. 230-237

[4]. Mike Ashmore (2013) - Air Pollution Encyclopedia of Biodiversity (Second Edition), Science Direct, pp. 136147

[5]. Dwyer, L., \& Kim, C. (2003). Destination Competitiveness: Determinants and Indicators. Current Issues in Tourism, 6(5), pp. 369-414. doi:10.1080/13683500308667962

[6]. Mieczkowski, Z. (1995). Environmental issues of tourism and recreation, London, University Press of America, pp. $109-132$

[7]. M. J. Stabler, Middleton, V. T. (1997). Sustainable tourism: A marketing perspective, Tourism sustainability. Wallingford: CAB International, pp. 129-142

[8]. Mihalic T., (1999). Environmental management of tourist destinations: a factor of tourism competitiveness. Tourism Management. 21, pp. 65 -78

[9]. Singal S.P. (2012) - Air Quality Monitoring and Control Strategy, Alpha Science International, Oxford, Uk, pp. $80-120$

[10].Costa, S., Ferreira, J., Silveira, C., Costa, C., Lopes, D., Relvas, H., Borrego, C., Roebeling, P., Miranda, A.I. and Paulo Teixeira, J. (2014), - Integrating health on air quality assessment - review report on health risks of two major European outdoor air pollutants: PM and NO2, Journal of Toxicology and Environmental Health Part B Critical Review, Vol. 17 No. 6, pp. 305-330

[11].National Center for Environmental Health (2021) - Air Quality and Air pollutants [Online]. Available:https://www.cdc.gov/air/pollutants.htm

[12].Singh, T.V (2004) New Horizons in Tourism: Strange Experiences and Stranger Practices, Centre for Tourism Research and Development, A-965/6 Indira Nagar, Lucknow - 226 016, India, Chapter: 8, pp. 95-109

[13].Maxim A., Stana D., Grigoraș M. (2010)- [Alphabet of Ecology and agrotourism]-Cluj Napoca Risoprint, Chapter 3. pp 75-88

[14].Daniel Vallero (2014) - Fundamentals of Air Pollution (Fifth edition), Chapter 7 ,Air Pollutant Hazards”, pp. 197-214

[15].Rinbeck J., Stephan G., Thea C., Blanke J. (2008) Trends and Issues in Global Tourism, Chapter Improving Travel \& Tourism Competitiveness pp. 97108

[16].ANPM Bucharest (2014) - Global Sustainable Development [Online]. Available: http://www.anpm.ro/ro/dezvoltare-durabila

[17]. World Economic Forum (2019) -The Travel \& Tourism Competitiveness Report 2019 published by the World Economic Forum's Platform, [Online]. Available: http://www3.weforum.org/docs/WEF_TTCR_2019.pdf

[18].National Center for Environmental Health (2021) - Air Quality and Air pollutants [Online]. Available:https://www.cdc.gov/air/pollutants.htm

[19].European Environment Agency - European Air Quality Index (2020), [Online]. Available: https://www.eea.europa.eu/themes/air/air-qualityindex/index

[20]. World Health Organisation (2017) - Evolution of WHO air quality guidelines: past, present and future. Copenhagen: WHO Regional Office for Europe
[21]. World Health Organisation (2017) - Evolution of WHO air quality guidelines: past, present and future. Copenhagen: WHO Regional Office for Europe

[22]. World Economic Forum (2019) -The Travel \& Tourism Competitiveness Report 2019 published by the World Economic Forum's Platform, [Online]. Available :http://www3.weforum.org/docs/WEF_TTCR 2019.pdf

[23]. World Economic Forum (2009) -The Travel \& Tourism Competitiveness Report 2009 published by the World Economic Forum's Platform [Online]. Available:http:/www.ontit.it/opencms/export/sites/defa ult/ont/it/documenti/files/ONT_2009-03-04_02101.pdf

[24]. World Economic Forum (2011) -The Travel \& Tourism Competitiveness Report 2011 published by the World Economic Forum's Platform [Online], Available: http://www3.weforum.org/docs/TTCR11/

[25]. World Economic Forum (2013) -The Travel \& Tourism Competitiveness Report 2013 published by the World Economic Forum's Platform [Online]. Available:http://www3.weforum.org/docs/WEF_TT_C ompetitiveness_Report_2013.pdf

[26]. World Economic Forum (2015) - The Travel \& Tourism Competitiveness Report 2015 is published the World Economic Forum's Platform [Online]. Available:http://www3.weforum.org/docs/TT15/WEF Global_Travel\&Tourism_Report_2015.pdf

[27]. World Economic Forum (2017) -The Travel \& Tourism Competitiveness Report 2017 published by the World Economic Forum's Platform [Online]. Available:http://www3.weforum.org/docs/WEF_TTCR 2017_web_0401.pdf

[28].Celeste E., Maria J. C., Mara M., Margarita R., Víctor R., Michael R., Hélder R., Carla G., Myriam L., Vania S., Carlos B., Alexandra M. (2020) - The impact of air quality on tourism: a systematic literature review, Journal of Tourism Futures.

[29]. Mihalic T., (1999). Environmental management of tourist destinations: a factor of tourism competitiveness. Tourism Management. 21, pp. 65 -78

[30].Saenz-de-Miera O., Rossello J. (2013) -Tropospheric ozone, air pollution and tourism: a case study of Mallorca, Journal of Sustainable Tourism, Vol. 21, pp. 1198-1230.

[31]. Rossello-Nadal, J. (2014), - How to evaluate the effects of climate change on tourism, Tourism Management, Vol. 42, pp. 332-341

[32].Sajjad, F., Noreen, U. and Zaman, K. (2014), Climate change and air pollution jointly creating nightmare for tourism industry, Environmental Science and Pollution Research, Vol. 21 No. 21, pp. 12403-12418.

[33].Cucculelli M., Goffi G. (2016) - Does sustainability enhance tourism destination competitiveness? Evidence from Italian Destinations of Excellence. Journal of Cleaner Production, pp. 370-382.

[34].Widjaja, Y. I., Khalifa, G. S. A. \& Abuelhassan, A. E. (2019). The Effect of destination reputation on the revisit intention to halal tourism destination of Jakarta. International Journal of Business, Economics and Law, 20(5), pp. 104-111

[35].Global Sustainable Tourism Council (2019) Global Travelers prefer eco-friendly accommodation: Booking.com Sustainable Travel Report, [Online]. Available: https://www.gstcouncil.org/booking-comsustainable-travel-report-2019 